\title{
German Foreign Policy towards the Romanian Oil during 1938-1940
}

\author{
Gavriil Preda
}

\begin{abstract}
In 1938, Europe's geographical situation changed considerably. After Austria's annexation by Germany, in March 1938, and the division of Czechoslovakia, the FrenchBritish hegemony in Central and Southeastern Europe came to an end. The decline of the French and British power forced Romania to take into consideration the increase of the German influence in Central and Eastern Europe and the evolution of the Soviet Union's foreign policy. Geopolitical evolutions favored Germany, which was interested in gaining control over Romanian oil reserves, the second largest oil products exporter in Europe. Consequently, during the period 1938 - 1941, Germany developed a coherent offensive strategy, acting across multiple levels simultaneously: political-diplomatic, military and economic, in order to ensure control over the Romanian oil, essential strategic raw material for its war economy. At the same time, Romania has its own defense strategy, within which oil played a very important role. Analyzed from a historical perspective, Romanian-German relations from 1938-1940 provide viable conclusions even nowadays, regarding the realist strategies that small-sized states with oil resources can adopt in their dispute with the great powers.
\end{abstract}

Index Terms-Oil, weapons, war economy, diplomacy.

\section{INTRODUCTION}

During the two world wars, oil had a vital role for belligerent states. During the inter-war period, oil became very important under the circumstances created by army motorization processes and by the spectacular increase of military troops. The strategic importance of oil reserves increased after 1938, under the increasing risk of yet another world war. The dependence of the great powers on oil imports forced them to elaborate supply strategies with this vital raw material for the war economy. Based on data from archives, memoirs and works about the role of oil during World War II, the study analyzes Germany's strategy to ensure the import of Romanian oil, which was needed in its war economy. At the same time, the study aims at bringing new information to answer a series of questions that are still debated on within the history of World War II. First: why did Germany not use military force to strategically exploit Romanian oil, as it did on other occasions? Second: how important was Hitler's Germany's loss of the possibility to import oil from the Middle East? Third: what are the lessons to be learned today from the asymmetrical dispute between Romanian and Germany over the control of the former's oil

Manuscript received March 2, 2013; revised May 21, 2013.

Gavriil Preda is with the Faculty of History, Christian "Dimitrie Cantemir" University, Bucharest, and in period 2002-2010 was with the Petroleum-Gas University of Ploiesti, Romania (e-mail: gavriilpreda@yahoo.com). resources?

Geopolitical evolutions in Europe favored Germany in the competition against other great European powers over the oil reserves in Romania which, at that time, was considered the second largest oil products exporter in Europe. Consequently, during the period 1938 - 1940, Germany developed a coherent offensive strategy, acting across multiple levels simultaneously: political-diplomatic, military and economic, in order to ensure control over the Romanian oil, essential strategic raw material for its war economy. Romania was able to elaborate it own efficient strategy designed to counterbalance the German one in order to ensure its territorial security and integrity, while also using the 'oil' weapon.

\section{DISCUSSION}

World War I showed that the interdependency between the war economy and the fighting capacity of the state armed forces imposed itself as a vital relationship within the strategy to fight a long war. The importance of raw materials for a state's war potential became essential, and the logistical preparation of the war had to be planned for during times of peace. Pierre l'Espagnol de la Tramerye wrote that Armies, navies, money, even entire populations, will count as nothing against the lack of oil (pp. 11) [1].

All of the great European powers, except for the Soviet Union, were dependent, one way or the other, on oil imports. These countries' level of dependency on oil varied. Great Britain and France did not have important oil resources on their national territories, but they exploited large oil deposits located in their colonial empires. Germany and Italy, lacking significant domestic large oil reserves, were forced to import large quantities, especially from other continents. The asymmetry between the domestic oil production and consumption made the great powers very vulnerable to the import of this strategic raw material. Their total domestic production, except for the Soviet Union, was insignificant, compared to their domestic consumption, which reached almost 30 million tons (Germany -7.5 million tons, France -7 million tons, Great Britain - 12 million tons, Italy -2.9 million tons). The German domestic production in 1938 equalled approximately $3,000,000$ tons $(500,000$ tons obtained through natural extraction, while approximately 2,500,000 tons were produced synthetically) (M.P.R. (1940) [2]. At the same time, Germany imported 4.5 million tons of oil (3.415 million tons from other continents, 704,432 tons from Romania and 80,000 tons from the Soviet Union) (M.P.R. (1939) [3], of which about $75 \%$ from outside Europe. In the case of a conflict against Great Britain and France, Germany's possibilities to import oil from other 
continents were very slim. Consequently, it was forced to find oil supply sources from Europe.

The interest of the great European powers towards the Romanian oil was unequal during the inter-war period. The increasing likelihood of a world conflict suddenly amplified the economic-military importance of the Romanian oil. At the European level, Romania was the second largest producer, its oil reserves being surpassed only by those of the Soviet Union. From this point of view, Germany's interest for the Romanian oil vas vital, because the access to other important oil sources around the globe and their control was almost impossible (A.N.I.C.) [4]. Romania had large oil deposits, according to table I, but also an important geopolitical position in Central and South-Eastern Europe.

TABLE I: Evolution of THE RoMANIAN OIL PRODUCTION DURING THE PERIOD 1936-1940 ${ }^{\mathrm{A}}$

\begin{tabular}{|l|l|l|l|}
\hline Year & $\begin{array}{l}\text { Total } \\
\text { production (in } \\
\text { tons) }\end{array}$ & $\begin{array}{l}\text { Domestic } \\
\text { consumption (in } \\
\text { tons) }\end{array}$ & $\begin{array}{l}\text { Export (in } \\
\text { tons) }\end{array}$ \\
\hline 1936 & $8,704,000$ & $1,820,000$ & $6,884,000$ \\
\hline 1937 & $7,153,000$ & $1,485,000$ & $5,668,000$ \\
\hline 1938 & $6,610,000$ & $2,116,000$ & $4,494,000$ \\
\hline 1939 & $6,240,000$ & $2,023,000$ & $4,177,000$ \\
\hline 1940 & $5,810,000$ & $2,308,000$ & $3,492,000$ \\
\hline
\end{tabular}

a Gheorghe Buzatu, A history of Romanian oil, Editura Mica Valahie, Targoviste, 2004, pp. 46-50

Three aspects can be noticed: a constant decline in the raw oil production after 1936, internal consumption of almost $30 \%$ of the total production and greater export availability for oil products. The Romanian export of oil products being higher than 4,000,000 tons annually, it could cover approximately $60 \%$ of the German domestic consumption.

In Romania, there were over 40 refineries operating, whose technological processing capacity reached 9,386,500 tons annually. These refineries could supply oil products necessary for the modern armies of those times, and in large quantities. The oil products transport infrastructure in Romania was modern and diversified. The oil hub of Ploieşti was connected to oil ports of Constanta and Giurgiu through pipelines with a transport capacity of approximately $1,000,000$ tons annually. Constanta's oil products transit capacity reached 5,000,000 tons annually, while that of the Giurgiu port was of 1,200,000 tons annually. The Romanian railway system had a total of 10,166 oil products transport wagons, reaching large European consumers or oil ports. In parallel, on the Danube there was a river fleet of cistern vessels, with a transport capacity of approximately 200,000 tons. The storage capacity of the products specific for the Romanian oil industry was of 3,161,337 tons (A.N.I.C.) [5]. The control over the oil fields in times of war and of the Romanian geographical area provided Germany with special advantages: the annulment of the effects generated by the maritime blockade created by the adversaries regarding the oil supply, and the possibility to continue its expansion towards the East and the Balkans.

The German action to gain control over the Romanian oil was an important phase in the geopolitical project of the Third Reich, regarding the creation of the economic space. Bilateral Romanian-German relations during the inter-war period were dominated, at the political level, by fundamental differences regarding the position towards the border revision policy, supported by Germany (Chiper I. (2000) [6]. In the economic area, there was increasing concern regarding the development of trade relations. The low level of political relations hindered the development of the bilateral trade relations. Austria's annexation by Germany, on March 12, 1938, ruined the force balance in Central Europe and led to an essential change in the international position of all states in the region. The events in Austria were not accidental; they only represented a phase in the German expansion plan along the Danube in order to conquer outlets and raw materials in the East (Călinescu A., (1990) [7]. After Austria's annexation, the Romanian government took measures to consolidate the country's domestic and international position. At the national level, the political activity of the Legionary Movement, a pro-German political party, was forbidden. Externally speaking, talks were initiated with the French and British governments, because Romania had to take into account the new international status quo. From the military point of view, it was noticed that, after Austria's annexation by Germany, the imminent danger was coming from the West, from Hungary, and especially from Germany, even if the Soviet Union remained the same important enemy (A.M.R.) [8]. The political line adopted by Germany towards Romania, after the Anschluss, was a cautious one. "We shall treat the matter of Romanian-German relations with promptness, avoiding the establishment of other unwanted ties through any weakening of our relations", stated a document of the German foreign affairs minister, dated April 6, 1938. In the opinion of the Berlin authorities, it was to be expected for the development of trade relations between the two countries to work in favour of Germany (A.S.W.) [9]. Adolf Hitler told the Romanian Minister to Berlin, on April 22, 1939, that he only had economic objectives in Romania, stating that Germany was not interested in the territorial issues between Balkan countries (A.S.W.) [10]. It was a very important statement for the Romanian government, which was confronted to the Hungarian and Bulgarian revisionist policy. The Romanian government's need to make massive war material purchases favoured Germany in its relations with Romania. Quick and satisfactory deliveries of armament are the best means through which the German influence could increase in Romania (A.S.W.) [11]. Rearranging the forces between the European powers, after the Munich agreement (September 29-30, 1938) showed that Romania became more and more dependent on Germany, both economically and geopolitically. Within the Romanian political system, there was a fundamental change in the attitude towards Germany (A.S.W.) [12]. The crisis in the political relations between Bucharest and Berlin between November 1938 and March 1939 influenced the negotiations for a new agreement (A. D. A. P.) [13]. On December 10, 1938, a commercial agreement was signed with Germany, which included 14 separate protocols and conventions. The agreement stipulated that the amount of bilateral economic exchanges reached 250 million marks (10 billion lei) in 1939. Through that agreement, Romanian undertook to export oil to Germany to the amount of 60-65 million marks. (A. M. A. 
E.) [14] Germany managed to change the leu/mark ratio, from $39 / 1$ to $41.5 / 1$, which was an advantage for the German import of Romanian goods. Between February 13 and March 23, 1939, Romanian-German negotiations took place in order to conclude a long-term economic agreement and were carried out in a tensed political (Moisuc V. (1991) [15], diplomatic (Haynes R. (2003) [16] and military context (Simion A. (1983) [17]. The coordination of Germany's actions with those of Hungary against Czechoslovakia and the concentration of Hungarian troops on Romania's Western border were pressure and intimidation means against the Bucharest government (Marguerat Ph. (1977) [18]. On March 23, 1939, the Economic Romanian-German Treaty was signed in Bucharest, representing the last phase of the geopolitical project of creating the Wirtschaftsraum through peaceful means, and because of its provisions, represented a new novelty in the practice of the international economic relations. The agreement was a success for Germany from two points view: it created the legal framework to enter the Romanian economy, including in the oil industry, and it did not set any political engagement for Romania regarding the guarantee of border integrity (Preda G. (2001) [19]. France and Great Britain understood that, by using Romania's wealth, especially the oil, Germany significantly improved its own raw materials supply necessary to carry on a war (Hillgruber A. (1994) [20]. After the signing of the Romanian-German treaty of March 23, 1939, Great Britain and France reacted through political-diplomatic and economic measures. On March 31, 1939, France signed an economic agreement with Romania, while on May 11 and June 12, 1939, Great Britain signed a protocol and an economic agreement with Romania. Western powers undertook to buy oil and cereals from Romania and to grant credits to purchase armament from Great Britain and France. Within the same context, there were unilateral FrenchBritish guarantees given to Romania and Greece. The guarantees were equivocal, inoperative at military level (D. B. Funderburk (1982) [21] and they created additional difficulties for Romania in its relations with Germany and Italy. The acceptance of the guarantees created an unfavourable impression in Berlin, being considered as an add-on to Germany's circling policy (A. D. A. P.) [22]. The Ribbentrop-Molotov Treaty of August 23, 1939 was a shock for the Romanian foreign policy. Romania's security system, based on interconnected alliances and on the balance strategy between dominating powers in Central and SouthEastern Europe, was annulled. Isolated from its traditional allies, France and Great Britain, Romania was confronted with a strong German and Soviet pressure.

The world war started on September 1, 1939 depended on oil, which was essentially important (Berreby J. J. (1961) [23] in the way the conflict unfolded. Oil became a war weapon, being equally important both for belligerents and for non-belligerents (Buzatu Gh. (1998) [24]. Under the newly created international context, Romania declared its neutrality on September 6, 1939. However, neutrality did not spare it from strong pressures from conflicting great powers, all being interested in Romania's oil. The Berlin government asked Romania to respect the oil agreements signed with Germany (A. M. A. E.) [25]. The issue of oil supply became extremely pressing for Germany, following the experience of the Poland campaign. In order to impose its control over Romanian oil, Germany intensified and diversified its means of pressure on the Bucharest government. The crashing victories over Poland, Denmark, Norway, France, Belgium, and the Netherlands, during the period September 1939 - June 1940, turned Germany into the largest power in Europe. The Romanian-German economic relations during the period September 1939November 1940 were strongly affected by the oil factor. Several bilateral conventions were signed, through which the German side sought to eliminate restrictive clauses regarding the amount of oil products exported to Germany. The Romanian side accepted these changes in order to be able to buy armament. On September 29, 1939, a Confidential Protocol was signed, stating that Romania bought war materials worth 100 million marks, while exporting to Germany 600,000 tons of oil products (A.M.A.E.) [26]. In December 1939, a new clearing agreement was signed, through which Romania undertook to export 130,000 tons each month to Germany. The same agreement created an important advantage for the German side, through the modification of the currency exchange rate, from 40.5 lei $/ 1$ mark to 50 lei/1 mark (A. M. A. E.) [27]. During March-May 1940, new bilateral economic negotiations took place, the German government being interested in deepening economic and trade relations (A. M. A. E.) [28]. Through the Provisory Convention signed on March 6, 1940, Germany undertook to sell 410 cannons to Romania, while the Romanian government authorized the additional export of 200,000 tons of oil products in March and April (A. M. A. E.) [29]. On May 27, 1940, the Armament-Oil Pact was signed, one of the most important economic documents between Germany and Romania, which set a fixed ratio between armament and oil prices. The price of armament was set to half of the one prior to the war, while the price of oil was set at the level of JulyAugust 1939. The agreement signed on May 27, 1940 meant a double victory for Germany. At the economic level, it obtained a reduction of the oil price by approximately one third as compared to the price of those times. Politically speaking, it managed to completely eliminate the English domination on the Romanian oil market (A. N. I. C.) [30]. As shown in Table II, the effect of the signed convention led to a constant increase of the oil products quantity exported to Germany.

TABLE II: THE EXPORTS OF OIL PRODUCTS TO GERMANY, DURING THE PERIOD APRIL - OCTOBER $1940^{\mathrm{C}}$

\begin{tabular}{|l|l|l|l|l|l|l|l|}
\hline Month & April & May & June & July & August & $\begin{array}{l}\text { Septemb } \\
\text { er }\end{array}$ & October \\
\hline $\begin{array}{l}\text { Quantity } \\
\text { (in tons) }\end{array}$ & 49,855 & 104,231 & 94,251 & 193,243 & 186,850 & 139,075 & 196,343 \\
\hline
\end{tabular}

${ }^{c}$ A.M.A.E., fond Arhiva Economică, vol. 83.

Germany's extremely strong military force of the springsummer of 1940, the hostility of adverse neighbouring countries and the lack of any French-British help were the factors that determined Romania to make important economic concessions for Germany in terms of oil. In 
exchange for the accepted economic exchanges, Romania sought Germany's support in defending its territorial integrity and independence against the Soviet, Hungarian and Bulgarian revisionism. The evolution of bilateral relations of the following months showed that Germany only pursued its geopolitical interests with respect to the Romanian oil. Germany made a constant effort to prevent any conflict that might put in danger the safety of the Romanian oil industry. This is the reason which explains the agreement to the secret clause of the Molotov-Ribbentrop treaty which allowed the Soviet Union to annex by force the Romanian province Bassarabia (June 28 $8^{\text {th }}, 1940$ ) and Hungary to attach $43,000 \mathrm{sq}$. km of the Romanian territory (August 30, 1940), thus making it possible for the German troops to arrive $80 \mathrm{~km}$ close to the Romanian oil fields. German and Romanian intelligence worked efficiently to stop all sabotage actions performed by Great Britain against the Romanian oil; industry. During the same strategy Germany satisfied the territorial claims of Soviet Union, Hungary and Bulgaria and in the same time "guaranteed" the existence of the Romanian state.

The domestic political crisis that occurred in Romania after the severe territorial losses led to arrival, in September 1940 , of a pro-German government to run the country, led by General Ion Antonescu. The Ion Antonescu government gave up the neutrality and chose the economic and political collaboration with Germany to ensure the survival of the Romanian state. Upon the request of the Romanian government, the Führer approved, on September 19, 1940, the sending of a German military mission to Romania, as training troops. The real task of the military mission was to protect oil fields from being taken over by a third power or against destruction (D. G. F. P.) [31]. German troops arrived in Romania in October-November 1940.The deployment of German troops in the strategic zones in Romania (after October 12, 1940) and after the Romania joined in the Axis (November 23, 1940) were the de facto instauration of the German control over the oil in Romania.

\section{CONCLUSION}

The Romanian-German economic, political, diplomatic and military relations during the period 1938-1940 largely depended on the oil factor. The loss of the strategic initiative to import oil from other continents, especially from the Middle East, forced Germany to obtain the necessary oil from Europe. In order to control Romanian oil, it chose the political-diplomatic way for strategic reasons: it was about to attack the Soviet Union and it needed stability for a proper functioning of the Romanian oil industry. Romania had the capacity to elaborate an efficient strategy to counterattack a possible military occupation of its territory by Germany. The evolution of Romanian-German relations in the analyzed period allows for several conclusions which continue to be valid in international relations. Countries rich in oil can become, under certain circumstances, areas of geopolitical dispute for the great powers. Today the survival of such countries depends on the realism with which they elaborate their counter-attack strategies within such contexts.

\section{REFERENCES}

[1] Pierre l'Espagnol de la Tramerye, The World Struggle for Oil, Alfred A. Knotf Inc., New York, USA, 1924.

[2] Moniteur du Pétrole Roumain (hereafter M. P. R.), vol. 45, no. 12, 1940, pp. 657-664.

[3] M. P. R., vol. 44, no. 4, 1939, pp. 218.

[4] Arhiva Naţională Istorică Centrală (hereafter A. N. I. C.), fond Germania, microfilme, rola 12, M 018.

[5] Arhiva Naţională Istorică Centrală, fond 1883, dosar 108, pp. 56.

[6] I. Chiper, România şi Germania nazistă. Relațiile româno-germane intre comandamente politice si interese economice (ianuarie 1933martie 1938), Editura Elion, București, 2000, pp. 34.

[7] Armand Călinescu, Însemnări Politice, Editura Humanitas, Bucuresti, 1990, pp. 23.

[8] Arhivele Militare Române (hereafter A. M. R.), fond Marele Stat Major, dosar 51, pp. 757.

[9] Les Archives secrètes de la Wilhelmstrasse (hereafter A. S. W.), vol. 4, (juin 1937 - mars 1939), Paris, 1954, document no. 33.

[10] A. S. W., vol. 5, livre I, document no. 181.

[11] A. S. W., vol. 5, livre I, document no. 190.

[12] A. S. W., vol. 5, livre I, document no. 215.

[13] Akten zur Deutschen Auswärtigen Politik 1919-1945, (hereafter A.D.A.P.), Serie D (1937-1945), Band VI März. bis Aug. 1939 MCMLVI, Baden - Baden, vol. 7, document no. 264.

[14] Arhiva Ministerului Afacerilor Externe (hereafter A.M.A.E.), fond 71, Germania, vol. 76 bis, pp. 26-29.

[15] V. Moisuc, Premisele izolării Politice a României. 1919-1940, Editura Humanitas, București, 1991. pp. 35-42.

[16] R. Haynes, Politica României față de Germania înttre 1936-1940, Editura Polirom, Iași, 2003, pp. 89.

[17] A. Simion, Agresiunile Naziste din Europa din anii 1938-1939, Editura Eminescu, București, 1983, pp. 127.

[18] P. Marguerat, Le III Reich et le péTrole Roumain, 1938-1940, A. W. Sisjthoff-Leiden, Institut Universitaire de Hautes Internationales, Genève, 1977, pp. 133.

[19] G. Preda, Importanța Strategică a Petrolului Românesc 1939-1947, Editura PrintEuro, Ploiești, 2001, pp. 60-63.

[20] A. Hillgruber, Hitler, Regele Carol şi Mareşalul Ion Antonescu. Relaţiile Româno-Germane (1938-1944), Editura Humanitas, Bucureşti, 1994, pp. 190-191.

[21] D. B. Funderburk, Politica Marii Britanii față de România (19301940) Studiu Asupra Strategiei Economice și Politice, Editura Științifică și Enciclopedică, București, 1982, pp. 163.

[22] A. D. A. P., vol. 7, document no. 227.

[23] J. J. Berreby, Histoire Mondiale du Petrole, Editions du Pont Royal, Paris, 1961, pp. 207.

[24] G. Buzatu, O Istorie a Petrolului Românesc, Editura Enciclopedică, București, 1998, pp. 315.

[25] A. M. A. E., fond 71/ Germania, dosar, vol. 78, pp. 2, 21.

[26] A. M. A. E., fond Tratate, Convenții, Acorduri, Protocoale, Germania, 45 terțiar.

[27] A. M. A. E., fond Tratate, Convenții, Acorduri, Protocoale, Germania, 46.

[28] A. M. R., fond 948, dosar 725, pp. 32.

[29] A. M. A. E., fond Tratate, Convenții, Acorduri, Protocoale, Germania, 49.

[30] A. N. I. C., fond 10, dosar 12, pp. 139.

[31] Documents of German Foreign Policy (hereafter D.G.F.P.), 19181945, Series D, vol. 10, June 23-August 31, 1940, Her Majestys Stationery Office, London, 1957, document no. 84.

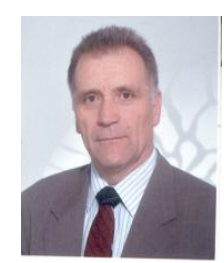

G. Preda was born in Romania on August 15, 1955. He graduated Faculty of Military Policy in 1986 and Command and staff Faculty in 1993 from "Carol I" National Defense University Bucharest. He took his PhD in History in 2000 at "Alexandru Ioan Cuza" University Iași. Mr. Preda has the following degree: bachelor's degree and master's degree paper coordinator and head of department at the Faculty of History. The author's major fields of study are the following: universal contemporary history, military history, history of WWII and Cold War. He wrote 8 books and more than 65 research papers and scientific studies published international conferences, proceedings, national conferences and International and National Journals. Associate professor $\mathrm{PhD}$ G. Preda has the following memberships: Romanian Commission of Military History and Romanian Scientific Society Interdisciplinary Research, "Nicolae Iorga" History Club. 